\title{
Cell Death Process
}

National Cancer Institute

\section{Source}

National Cancer Institute. Cell Death Process. NCI Thesaurus. Code C41515.

The cellular process resulting in permanent cessation of all vital functions of a cell. 